\title{
Through Fire: Creative Aspects of Sacrificial Rituals in the Vedic-Hindu Continuum
}

\author{
Albertina Nugteren
}

\section{Introduction}

The place is Panauti, some 32 kilometres to the Southeast of Kathmandu, Nepal. The date is June 26, 2011. Standing on the Triveni-ghät (literally: 'the cremation platform at the three-forked confluence') I watch a corpse slowly burn to ashes. Situated on the extreme end of a wedge between two merging rivers this cremation platform is one of the most sacred places for Hindus in South Asia: two rivers are said to be joined by a third ('subterranean') invisible river, the mythic Padmāvatī, at precisely this point. Ashes scattered over this sacred confluence from which three rivers move forward as a single current are believed to float straight to heaven, making any further reincarnation of the deceased unnecessary.

The sheer physicality of a corpse (a person who had been alive less than 24 hours ago) being cremated on an open pyre placed directly in front of the sacred confluence of two rivers impresses itself on the senses in such a way that my mind opts out. Vivid intersensorial impressions take over my usual mental control. Such a lucid state of shock may not be to everyone's liking, but as a direct encounter with a burning body in the heat of a summer day I have literally faced death through all my senses.

In the course of almost four decades of fieldwork I have witnessed various sacrifices, as well as various open-air cremations, but it is here, in front of a pyre auspiciously placed where three rivers are said to mingle (even if only two are visible to the human eye), that the classic name for Hindu cremation, antyești, 'final sacrifice', acquires its full meaning. It is by giving one's own body as a sacrificial gift into the open fire that one of the deepest secrets of the sacrificial cult is fulfilled. Hindu sacrificial logic may have its flaws when applied in hasty humdrum machinations and routine priestly practices, but at death, by this sacred confluence, the system certainly makes sense. Its logic is both poetic and dramatic. How? And why is one's own dead body the ultimate sacrificial gift? What kind of god, what priest, what system of cosmic retribution would require such a gift?

The Hindu sacrificial complex is a many-hued fabric, an antique carpet woven with the shimmering threads of multiple myths and patterned practices. 
In order to unravel some of the main narratives underlying Hindu sacrifice I have to make choices. From the sheer limitless variety of mythic imaginations and esoteric inspirations found in ancient hymns and speculative texts I select four. I am well aware that the subjectively chosen pattern presented here celebrates a challenge of choices, a poetics of possibilities, a game within a gamble of endless combinations and explanations. In a way Vedic sacrifice itself may be characterized as a gamble, as in the words of Jan Heesterman:

It is the renewal of the past and the gamble for the future (...) deciding each time anew, through endless rounds of winning, losing, and revanche, the state of human affairs here and in the hereafter. ${ }^{1}$

In this contribution I try to make sense of Hindu sacrifice by focusing on four key narratives. Those narratives may provide clues to the enigma of sacrifice by offering an associative logic partially explaining the system. They are ancient cosmogonic stories in which, respectively, heat, dismemberment, milk and sperm figure as the key ingredients that determined sacrifice's decisive features. By picking out those four threads the fabric of the sacrificial system becomes 'readable', the pattern 'discernable'. And in the end, in order to understand why cremation ritual is still named 'the final sacrifice' today, we will return to our beginnings. But first we need a few words on the context in which the Vedic-Hindu sacrificial system unfolded over time, how the inherent violence was accounted for, and, more generally, how Vedic sacrifice became a topic in the academic study of religion.

Western academic engagement with Vedic sacrificial ritual has been intense ever since Vedic texts were studied, translated, commented upon, and made sense of in particular frames of interpretation. Apart from the near

1 Jan C. Heesterman, The Broken World of Sacrifice: An Essay in Ancient Indian Ritual (University of Chicago Press: Chicago, 1993), pp. $2-3$.

2 This subtitle is derived from the much-used phrase "yajño vai rtasya yonihn" (Śatapatha Brāhmana 1.3.4.16): "Sacrifice is the womb of order." There is a clear parallel to that other phrase "agnir vai yonir yajñasya" (śв 10.1.2.2; cp. śв 3.1.3.28): "Agni is the womb of sacrifice." For further sexual symbolism (womb, sperm etc.) in Vedic sacrifice, see notes 26 and 28. In particular, see Ganesh Umakant Thite, Sacrifice in the Brāhmanas (PhD dissertation University of Poona: Poona, 1975), p. 257 ff. 
impossibility to extract a coherent world view from this particular genre of priestly texts, Western interpretation of Vedic sacrificial practice in a comparative perspective has often suffered from an Abrahamic preoccupation with sacrifice as atonement: for sins or at least for infelicitous conditions in need of reconciliation. ${ }^{3}$ In contrast, many Hindu debates, apart from complicated matters of a tradition-technical nature, long tended to focus on issues such as the tension between, on the one hand, the desire for worldly goods or fame in the here-and-now, and on the other hand the ultimate desire for heaven or even the end of rebirth. ${ }^{4}$ To borrow David Mandelbaum's formulation of two quite distinct complexes of belief and prosaic religion in South Asian religions, and apply it to sacrifice, there is an ongoing pull between the "pragmatic complex" and the "transcendental complex". ${ }^{5}$ Clearly, it is acknowledged that the act of sacrifice is motivated by some sort of desire, ${ }^{6}$ be it of the pragmatickarmatic (this-worldly) or the transcendental-svārgik (heavenly) type. Whatever the intention behind a sacrifice may be, in the Hindu context any sacrificial ritual needs a stated intent (samkalpa) just as it needs a person (yajamāna) to whom the merits of the sacrifice would fall.

Today other preoccupations and tensions become visible. One of these is the high-Hindu abhorrence of the killing of animals in the sacrificial arena. ${ }^{7}$

3 For a general and comparative orientation I used, among other works, Jeffrey Carter (ed.), Understanding Religious Sacrifice: A Reader (Continuum: London/New York, 2003); Robert G. Hamerton-Kelly (ed.), Violent Origins: Walter Burkert, René Girard, and Jonathan Z. Smith on Ritual Killing and Cultural Formation (Stanford University Press: Stanford, 1987); Albert I. Baumgarten (ed.), Sacrifice in Religious Experience (Brill: Leiden/Boston, 2002); Ivan Strenski, Theology and the First Theory of Sacrifice (Brill: Leiden/Boston, 2003); Rick F. Talbott, Sacred Sacrifice: Ritual Paradigms in Vedic Religion and Early Christianity (P. Lang: New York, 1995).

4 For views from Indian authors, see, for instance, Ganesh Umakant Thite, Sacrifice in the Brāhmaṇa-texts (see note 2); Naama Drury, The Sacrificial Rtual in the Satapatha Brāhmaṇa (Motilal Banarsidass: Delhi, 1981); Veena Das, 'Language of Sacrifice', MAN 18 (3) (1983), pp. 445-462; George Praseed, Sacrifice and Cosmos: Yajña and the Eucharist in Dialogue (Decent Books: Delhi, 2009).

5 David G. Mandelbaum, 'Transcendental and Pragmatic Aspects of Religion', American Anthropologist (New Series) 68 (5) (1966), pp. 1174-1191.

6 Although the word desire (käma) is used here, it refers to a technical discussion about distinctions in motivations for organizing rituals, one of which is indicated as kämya (connected with an explicit desire for stated results), and should not be confused with the discussion on Girard's theories on 'mimetic desire', which presents sacrifice as a substitution for some prior historic or mythic murder.

7 As in Herman W. Tull, 'The Killing that is not Killing: Men, Cattle, and the Origins of Non-violence (ahimsā) in the Vedic Sacrifice', Indo-Iranian Journal 39 (1996), pp. 223-244; J. E. M. Houben and K. R. van Kooij (eds), Violence, Non-violence and the Rationalization 
Another is the tendency to justify Vedic sacrificial rituals in terms of contemporary scientific insights, as occurs in the fields of ecology/environmentalism and of promoting social harmony. ${ }^{8}$ In this ongoing discourse, Vedic sacrifice is presented as an ahistorical technology that yields practical results and promotes public health, social cohesion, and the national economy. Its supposed rainmaking powers today still refer to early textual sources, echoed by many later apologists. A third contemporary preoccupation is the widespread superimposition of the interpretation of the Bhagavadgitan onto the sacrificial system. This implies for many that 'true' sacrifice is any action performed without a desire for personal good (nişkāma-karma); indeed, one's only desire should be for the common-cosmic good (lokasamgraha). Even though the scope of sacrificial effects may vary, from individual to community to society at large, even including the entire cosmos, sacrifice is seen as the womb of order (rtasya yoni), then as well as now.

At the same time anti-sacrifice articulations may almost be as old and as strong. One of the first historical figures opposing Vedic sacrifice is the Buddha, but he was far from unique in this. He may have been preceded as well as succeeded by nameless others - for instance, in circles of renunciants and yogis who opted out because of either definite anti-violence sentiments or a farreaching internalization of sacrifice. ${ }^{9}$ The gaze of Buddhism, Jainism, the Yoga school of philosophy, and the later devotional (bhakti) movements may well have been an influential factor in creating a fascinating curve in brahminic identity politics. In mid- and late Vedic times there had been some opposition against brahmin priests, who represented both the this-worldly (samsārika) technology of sacrificial merit and the killing of animals. In this light, it is striking that over the centuries the brahmins' position gradually turned into the exact opposite: they began to define themselves and their ritual activities more and more in terms of rigorous non-violence and purity. It is no coincidence that in contemporary India 'sāttvik' food, that is, 'pure' vegetarian (non-violent) food, is most closely associated with the brahmin class and highHindu temples and lifestyles. Although today both animal sacrifice (mainly by non-brahmin priests) and non-vegetarian food habits are much more widespread than scholars often perceive when assessing Hinduism-by-the-book,

of Violence in South Asian Cultural History (Brill: Leiden/Boston, 1999); Brian K. Smith and Wendy Doniger, "Sacrifice and Substitution", Numen 36 (20 (1989), pp. 189-224.

8 As in various articles in the Times of India in the first half of 2011, see notes 48 and 49 .

9 Yael Bentor, 'Internalized Fire Rituals in India and Tibet', Journal of the American Oriental Society 120 (4) (2000), pp. 594-613. 
over three millennia brahminic self-definition has undergone a radical shift in this regard.

Far from having died down, as was expected some decades ago, today public Vedic sacrifice has entered into new transnational and transcultural public spheres. Not only has it become a transnational phenomenon as a result of South Asian migration flows, also it has entered the domain of global wellbeing, religious environmentalism, public entertainment and the educational sector where it is presented as an archaic spectacle, an art form, and a living museum. To put things into perspective, it should be noted that sacrificial offerings are still part and parcel of lived religion in South Asia, albeit in considerably more modest forms than the grand spectacles of royal Vedic sacrifices which erroneously tend to be taken as the standard for what Vedic sacrifice in its heydays might have been. ${ }^{10}$ In this regard, it should be pointed out that traditionally there are two types of sacrifices: obligatory (nitya) and optional (kāmya). Sacrifices were obligatory for those qualified males who had established their own sacrificial fire(s) at home. Once someone had established these fires (after completion of his Veda study, after marriage, or after his father's death), they had to be maintained on a daily, monthly, and annual basis. Domestic sacrificial fires could also serve as the source for other sacrificial fires, such as the firebrand used for lighting the funeral pyre. Maintaining one or three (never two, as this would bring bad luck) domestic fires brought a life-long commitment. In a way such priests kept their fires going for the cosmic good. In contrast, optional sacrifices were performed according to individual wishes. These sacrifices were performed at the request of a ritual patron (yajamāna) on special calendrical occasions or when he wanted to obtain specifically stated ends such as health, wealth, or other forms of success. In such cases, the priest was merely the facilitator.

Theories on ritual sacrifice mostly derive their ideas from the Western world with its focus on sacred texts as well as from the theories of Western anthropologists based on the particular places where they had collected their field data. Some of the theorizing about the origin and function of sacrifice has indeed been applied to the South Asian situation and has been inspired by it at the same time. From Marcel Mauss to Veena Das, from René Girard to Kathryn McClymond, and from Sylvain Lévi to Jan Heesterman, Catherine Bell, Frits Staal, Wendy Doniger, Axel Michaels and Frederick Smith: there is

10 Frederick M. Smith, The Vedic Sacrifice in Transition (Bhandarkar Oriental Research Institute: Pune, 1987). See also Brian K. Smith, 'Vedic Fieldwork', Religious Studies Review 11 (2) (1985), pp. 136-145. 
an ongoing reflection on aspects of Vedic sacrificial ritual that finds its way to global debates on ritual studies. ${ }^{11}$

Varying from simple heart-felt expressions of gratefulness for a rich harvest to staggeringly complicated ritual actions of communion and communication, sacrifice in the Vedic-Hindu continuum covers the entire range from token gifts (dāna) to the gods to a complex world-maintaining activity (lokasamgraha). In many cases, various distinct elements are interwoven, and any attempt to reduce them to a single theory is to lose sight of the variety, the complexity, and the living reality.

The Enigma of Existence

We are faced with the astonishing fact that the Vedas, first sung on the Indian subcontinent around 1500-1200 $\mathrm{BCE}$, but probably reflecting much earlier gestation processes, were not written down until just a few hundred years ago. The verses of the Rgveda had been memorized and finally codified in Vedic Sanskrit before or around 1000 BCE. The 'proper' performance of their sacred rites was a matter not only of an extremely and increasingly demanding technical 'knowledge' and performative expertise, but also of 'understanding' a number of riddles, enigmatic phrases, rhetorical questions, and esoteric imagery. Possible answers to such enigmas may have provided keys to the mysterious power that supposedly made sacrifice effective and held together the universe as a whole. The person who could come up with a plausible answer (known as a brahman) was considered worthy of performing those rituals. This

11 Examples of this are: Barbara A. Holdrege (ed.), 'Ritual and Power; based on the Proceedings of the Santa Barbara Conference on Ritual and Power', a thematic edition of Journal of Ritual Studies 4 (2) (1990); René Girard's French publication Le Sacrifice (Bibliothèque nationale: Paris, 2003; English translation published as Sacrifice (Michigan State University Press: East Lansing, 2011), in which he explores the Brāhmanas based exclusively on Sylvain Lévi's La Doctrine du Sacrifice dans les Brāhmaṇas (Ernest Leroux: Paris, 1898). As in Girard's other work on sacrifice, he reads Vedic sacrifice in terms of violence, albeit 'muted' violence, as is obvious in the term for killing: śam-, to pacify, put to rest. Kathryn McClymond, in her book Beyond Sacred Violence: A Comparative Study of Sacrifice (The Johns Hopkins Press: Baltimore, 2008), argues that by going beyond this focus on ritual killing one can come to a more polythetic understanding of sacrifice. See also her earlier article, 'The Nature and Elements of Sacrificial Ritual', Method \& Theory in the Study of Religion 16 (2004), pp. 337-366. A wide array of ritual dynamics in various fields of studies, including sacrifice, is found in Axel Michaels (gen. ed.), Ritual Dynamics and the Science of Ritual 1-5 (Harrassowitz: Wiesbaden, 2010-2011). 
'solution' or right answer indicated a deeper understanding of the link that bound all things together: the very term for this mystifying secret that made sacrificial acts effective, brahman, denoted a power that could be known and manipulated as a way to re-integrate and maintain the world. The performance of Vedic sacrifice thus gradually became a rite of ontological significance on which all cosmic order $(r t a)$ was believed to depend.

The visions of the Vedas were to be sung, not merely stated, as well as ritually performed. In the world of Vedic sacrifice, the agency of the priestperformer was seen as crucial. He acted as a technician of the sacred, and should painstakingly stick to the regulations, as it was believed that a botched sacrifice could tilt the entire universe. ${ }^{12}$ Over time, Vedic ritualists construed a rational-mechanistic universe strictly contained within the ritual enclosure. Vast cosmic processes were reduced to the controlled world of the sacrificial process by setting up the identifications that anchored the macrocosm into the microcosm of all the discrete elements of the ritual process: the sacrificial field, the implements, the substances, the words, the acts, the actors. It was only later, by the time of the Upanișads, that some thinkers began to teach that a deeper understanding of the great Brahman, a term that indicates the encompassing source of any manifest sacrificial power (brahman), was more important than the outward performance of rituals themselves. Yet many priests went on to perform the sacred rites, with or without access to this profound underlying truth.

In a way, the ritual performance itself could be a gate to a gradually deeper understanding of the underlying forces. Imagination based on the original visions of the rșis made Vedic ritualists design a technology of the sacred, or, as Jan van Baal calls it, "a particularly effective means of communication with the universe."13 Rites were understood to contribute to (and even establish or re-establish) the radiance of all creation. And by going attentively through the ritual processes, the ritual performer could win deep insights. Whether this performer was a Vedic seer, a ritualist, or a contemplative yogi, at stake, ideally, was to envision, express, and tap into a powerful wholeness, Brahman. Vedic sacrificial ritual, then, was a tour of the imagination around 'being' itself: satya, a word that connotes both 'being' and 'truth'. The original visions of the Vedic seers, the intricacies of proper performance as well as the inner attunement

12 As in Ute Hüsken (ed.), When Rituals Go Wrong: Mistakes, Failure, and the Dynamics of Ritual (Brill: Leiden/Boston, 2007).

13 Jan van Baal, 'Offering, Sacrifice and Gift', originally published in Numen, volume XxiıI (1976), pp. 161-178. Reprinted in Jeffrey Carter (ed.), Understanding Religious Sacrifice: A Reader (Continuum: London/New York, 2003), pp. 276-291. 
to satya: all three were justified. They were culture-specific attempts at reintegration and rejuvenation of a once-established truth. But why reintegration? What had happened, what had gone wrong?

From the Vedic textual perspective the world may be praised as a wonderful place - shimmering with light, rosy with dawn, bursting with fertility, and softly glowing with the tranquility of dusk when the cows come home for the night - but it is a world never to be taken for granted. It is a world constantly under threat of fraying at the edges, of getting old and tired, and of losing its coherence by forces of disintegration and dissolution. This may sound as nothing particularly dramatic; death, decay and dissipation are simply the disturbing facts of life. Such forces of contingency were not necessarily considered to come from outside, as external enemies, or as the results of atrocities or sins committed by men; rather they were part of the game, inherent in the powerful wholeness of evolution. This wholeness - the manifested world, laukika - however, is a second-order state of things: it is derived from an earlier original state.

There is not necessarily an evil force at work here. Rather, precisely because the world has evolved from a primordial state of non-being at the very beginning (ägre), the arch towards death or dissipation is a natural corollary of existence. The more visionary of early Vedic thinkers thought that by regularly returning to that first creative moment, that generative burst of singularity into multiplicity, they could rejuvenate the world. ${ }^{14}$ It was imagined, by them, that this original 'event', this crucial and formative moment, had been a matter of heat and fire, an explosion of cosmogonic sparks flying forth from the very first 'body' in this universe, that of Purușa-Prajāpati. ${ }^{15}$ And this may explain why heat and fire are so constitutive in the whole sacrificial complex. ${ }^{16}$

14 In a totally different context, that of contemporary civil society, I gained deeper insights into the need for regular renewal of "emotional energy" (EE) through periodic repetition of rituals from Randall Collins, Interaction Ritual Chains (Princeton University Press: Princeton, 2004). For a creative and critical use of Collins' model of interaction ritual and ritual chains, see, among others, Elisabeth Summers-Effler, 'Ritual Theory', in Jan E. Stets and Jonathan A. Turner (eds), Handbook of the Sociology of Emotions (Springer: Dordrecht/New York, 2006), pp. 135-154, particularly pp. 138-139.

15 Pums or Puruṣa is the first Person, whereas Prajāpati means Lord of Creation. As both names are used rather indiscriminately and interchangeably throughout the Rgveda and Brāhmaṇa passages studied here, I hyphenated the two.

16 Perhaps unexpectedly, there is a tight connection with water as well: it is told that Agni, before he manifested himself in the cosmic drama, had been hiding in the depths of the primeval ocean. This makes Agni a central figure in two types of cosmogonic solutions: "the separation of creative fire from chaotic water and the creation by the ritual sacrifice 


\subsection{The First Narrative: Heat}

Our first sacred narrative holds that in the beginning Puruṣa-Prajāpati ('That One') existed all by himself. He was surrounded by unformed universe upon universe, splendid shimmering worlds of light and energy. But at some point he began to become conscious of himself, and to feel lonely. He was, essentially, a single being surrounded by nothing but yet-uncreated, undivided void. Upon this awareness he began to build up inner heat (tapas), and still more heat, so strong that finally he burst, and exploded, outward, in a tremendous blaze of sparks and glowing energy that filled the surrounding darkness of yetunformed life. ${ }^{17}$ All those luminous parts that flew from his body correspondingly formed the various regions, elements and beings in the world.

It was by this intense heat that the world was fashioned and that the One became many. ${ }^{18}$ Unified primeval truth had disintegrated into innumerable broken parts. Although Vedic poets may have been able to trace multiple reality back to that intuited primordial oneness, from that mythic cosmogonic moment onwards life is what it is: evolving, multiplying, distancing itself from its source, and therefore: dissipating, losing its energy, and thus in need of periodic renewal. We find, in this first narrative, some of the basic images constituting the Vedic worldview: heat, fire, sweat, sparks, eruption, resulting in division of the original wholeness, and disintegration into separate life forms.

\subsection{The Second Narrative: Dismemberment ${ }^{19}$}

Our second narrative views this aspect of a shattered primeval body from a slightly different angle. The crucial passage is as follows:

When, with Purușa as their offering, the gods performed the [first] sacrifice, (...) they anointed that primordial being, Purușa, in the form of a sacrifice (...) the gods sacrificed by means of him (...) and from that [first] sacrifice, that act of total giving, (...) [all creation] (...) was

of a god"; see George M. Williams, Handbook of Hindu Mythology (CLIO-ABC: Santa Barbara, Calif., 2003), p. 17. Specifically on heat, see Uma Marina Vesci, Heat and Sacrifice in the Vedas (Motilal Banarsidass: Delhi, 1985); on heat and fire, see David Knipe, In the Image of Fire: Vedic Experiences of Heat (Motilal Banarsidass: Delhi, 1975).

17 The term for creation is srstiti: what is poured forth. Srj- means to emit.

18 Main source: Taittirīya Brāhmaṇa 2.2.9, 1-10.

19 Dismemberment of the animal victim as a craft, and as an intricate cosmogonic reenactment, is elaborated upon in Charles Malamoud, 'Paths of the Knife: Carving up the Victim in the Vedic Sacrifice' in Indian Ritual and its Exegesis, ed. by Richard F. Gombrich, Oxford University Papers on India 2 (1) (Oxford University Press: Delhi, 1988), pp. 1-14. 
obtained, when gods, offering sacrifice, tied up Purușa as the sacrificial animal. With this sacrifice the gods sacrificed with/to sacrifice. ${ }^{20}$

In this additional vision, the setting in which the creative drama is played out is no longer a void. Purușa-Prajāpati no longer dwells strictly alone. Although shady, vague, unsubstantial, merely present at the margins, barely there, somehow other beings exist alongside him. They may be no more than his own meandering thoughts, turning into nameless assistants (or, if one wishes, opponents, henchmen even). And essentially he is still one and whole, but at the brink, in darkness, gods, seers and sages hover. ${ }^{21}$ Who are these gods? Are they faceless deities, nascent forces, shadows, mere figments of his own imagination? Whatever these gods are, they have some agency. They may merely have executed his will. Nevertheless, they were considered to have been instrumental in the first foundational sacrifice. Also, who are those seers mentioned here, presented as visionaries brought onto the stage as witnesses, as narrators, as poet-singers, as scribes who could record the 'events' in glowing visions to future humankind? Cosmic drama indeed, with scribes sitting ready with their writing tablets in order to record it for posterity.

Naturally, many questions remain. In our first narrative we found a mythic event in which such a fiery heat had built up in that first being that he exploded; from his shattered fragments this world came into being. This may be taken in an almost completely naturalistic vein. Creation 'happened' through a cosmogonic explosion. In our second narrative, however, there is no such linear logic. It goes around in circles, as it were. It circles around the image of a first being offering itself through the shady agency of rather insubstantial gods and under the eyes of narrators installed at the edge of the stage. Why did he make this resolve, what necessitated this drama of the first sacrifice, a self-sacrifice even? What necessitated this first sacrifice? Why this offer, this division, this distribution of matter through a conscious act of violence? The narrative, which recurs in various alternative text passages, sometimes paints a world in which there is nothing but this first being. In other passages, this being is indicated in all his vastness (Virāj) but already contains the main categories of the world known to us (such as gods, seers and sages). But whatever variations we may encounter, in the main phrases it is imagined that the order of the world, with all its known life forms, has come forth from this original act

20 Main source: Rgveda 10.90.1-16.

21 Rgveda 10.90.7. 
of sacrifice. This dramatic act of cosmogonic self-sacrifice thus forms the beginning of multiple existence. ${ }^{22}$

All creation originated from this initial sacrifice, whether self-willed or forced, in stages, in circles. The first being's own thoughts had served to produce the gods (and alternatively also seers, sages, and the paraphernalia for the sacrifice), and his own body subsequently served as the material from which the universe was organized through dismemberment and apportionment. ${ }^{23}$ Other passages relate that the gods came much later (famously formulated as: "the gods are on this side of creation"). Whatever their origin, this first category of created beings - vaguely and dimly present during the original sacrifice may well form an intermediate category, inter-beings between the One and the many. Their role, however, would later become more clear as some of those, the poet-singers, belonging to the class of the first 'witnesses', would mediate to the world the salvific institution of sacrifice. Sacrifice, on this account, was a precious gift to the world by those who remembered. Sacrifice, both ontologically and symbolically, is an imitation, a replay, a ritual re-enactment of the foundational 'event' they had been privileged to attend. When we focus on their role as mediators, suddenly the genius of the Vedic verses is revealed to us: if none had ever been present at such a literally groundbreaking event, how could we ever know? Would the world not be left alone, forever wondering, forever closed in on itself? Instead, silent witnesses, shady beings, vague presences at the margins of the cosmic stage are only indicated, as mere footnotes to the drama. Their vital importance, bridging the chasm between mythic time and present time, becomes clear only later: as divinely inspired poets they not only bear witness to the cosmogonic event, they also transmit the salvific tool to posterity: the institution of sacrifice.

\subsection{The Third Narrative: Milk}

Vedic sacrifice requires fire. In our third narrative, in a direct association with the first myth, in which heat had built up in that first being, we find the

22 On self-sacrifice, see Jan C. Heesterman, 'Self-sacrifice in Vedic Ritual', in Gilgul: Essays on Transformation, Revolution, and Permanence in the history of religion, ed. by Sha'ul Shaked and David Shulman (Brill: Leiden/Boston, 1987), pp. 91-106.

23 I have gratefully used Kathryn McClymond's emphasis on apportionment as one more parallel between the cosmogonic and the re-enacted sacrifice, in her book Beyond Sacred Violence (see note 11). It is telling that the chapter entitled "Liquid Sacrificial Offerings" is the largest in this book. She not only provides a corrective to the preoccupation previous scholars had with killing the animal victim, she delves deeper into the less spectacular liquid oblations such as vegetal juices and dairy offerings. 
centrality of fire. In the beginning he/it existed alone. He felt the urge to create, to multiply himself. In the process of heating up, he generated Agni (Cosmic Fire) from his mouth. And since Agni was generated from his mouth, Fire, eternally hungry, needs food. Predictably, this first creature, the ravenous Fire, turns towards Prajāpati as food. Preventing that he himself, Prajāpati, would become the first victim ever (as he actually was in the second narrative!) he inventively and creatively rubs his hands - and milk is produced. Ravenous Agni should have been happy with this (just as Vedic sacrificial fire is now very happy with milk oblations), but since Prajāpati had rubbed his hands in order to produce the first oblation, the milk was full of hair. Agni declined. Prajāpati could do nothing but throw away the milk-with-hair, and lo! This became the plants and trees on earth. ${ }^{24}$ When he rubbed his hands a second time, again milk was produced, but without hair this time, since he had rubbed his palms together, and human palms are without hair. ${ }^{25}$ Ever since, milk or its 'essence', clarified butter, has been one of the main oblations. ${ }^{26}$

After having created Agni, and having found a way to satisfy Fire's raving hunger, Prajāpati could continue with his creation-sacrifice. Sacrifice, in this version, was instituted by Prajāpati when threatened by his own offspring. In order to ward off being eaten alive by his own firstborn, he produced a nourishing liquid offering by rubbing his hands. So after he had used his own mind to create Fire, he used his own body to create milk and used it as dravya, the first and foremost sacrificial substance to be offered into the fire until today.

In South Asian narratives, we see that the motif of 'rubbing in order to create' is found in various contexts covering three millennia of storytelling and ritual practice. Not only is rubbing or friction one of the traditional ways to

24 On cosmogonies in relation to trees, see Chapter I in Albertina Nugteren, Belief, Bounty, and Beauty: Rituals around Sacred Trees in India (Brill: Leiden/Boston, 2005).

25 Main source: Śatapathabrāhmaṇa 2.2.4.1-8.

26 Surprisingly enough, milk or butter symbolism in the Vedic-Hindu continuum is hardly ever treated as a subject in its own right, whereas cattle are, such as in Deryck Lodrick, 'Symbol and Sustenance: Cattle in South Asian Culture' Dialectical Anthropology 29 (2005), pp. 61-84. Instead we find milk or butter listed as one of the main ritual substances ("tongue of the gods", "navel of immortality") in the Rgveda, or as auspicious food, such as in R. S. Khare, The Eternal Food: Gastronomic Ideas and Experiences of Hindus and Buddhists (suny Press: Albany, 1992) or in Arjun Appadurai, 'Gastro-Politics in Hindu South Asia' (American Ethnologist 8 (3) (1981), pp. 494-511. For the sexual connotations of milk, butter and ghī, see Wendy Doniger, Tales of Sex and Violence: Folklore, Sacrifice, and Danger in the Jaiminīya Brāhmaṇa (University of Chicago Press: Chicago, 1985). For a general treatment of milk as a vital substance in religious meaning-making practices in early civilizations, see Finbar McCormick, 'Cows, Milk and Religion: The Use of Dairy Products in Early Societies', Anthropozoologica 47 (2) (2012), pp. 101-113. 
produce sparks for the sacrificial fire (as by rubbing two pieces of dry wood together), the act of rubbing is considered to be generative par excellence. One example often retold in this regard is provided by the popular tale of the goddess Pārvatī, who for some reason could not entice her divine husband Siva to let her conceive in the natural way through completed sexual intercourse. In desperation, after having rubbed the skin of her arms, she created her famous and beloved son Ganeśa from the oily rub-offs produced from her own radiant skin.

As on a stage, we now have various characters: a first being, heat/sweat/ fire, the various officiants and their utensils, the great sacrifice, the basic order of existence, and sacrificial food. The last actor, the last requirement in this list, may not come as a surprise to us, because what/who is missing, at least in this selective combination of narratives, is a female. Remember it was not a gendered universe yet. What had evolved from Puruṣa-Prajāpati, in a two-step process, was essentially a non-gendered world. The first being had created by using his/its own imagination and body form as building material. This could well have worked out disastrously once Agni posed a serious threat: the firstborn turned against his progenitor to devour him. Ingeniously, this was averted by offering the ravenous Fire sacrificial milk (and creating the green world in the process, as a by-product; this is why one should not cry over spilled milk...). But in yet another version Prajāpati took the gendered route: our fourth narrative.

\subsection{The Fourth Narrative: Sperm}

Picture this first being, gradually turning into a person now, a male: he felt lonely, and desired a second being: "He looked around and saw nothing other than himself." He divided himself by falling (pat) into two pieces (the eternal dualism). In this way, from him, as pati (meaning lord as well as husband), a wife ( $p a t n \bar{l})$ was born. Inflamed with love and desire, he wanted to unite with her. But how could this be right when she was, in effect, his own daughter? Wanting to conceal herself from her father, this first woman fled. In the process of trying to escape her father, she disguised herself in various forms. When she fled as a doe, he became a stag and hunted her down. As he was on the point of mounting her, one of the gods, the fierce Rūdra, took his bow and shot an arrow to prevent the incestuous and violent act. This interruption caused Prajāpati's seed to be spilled prematurely. It fell on the ground and formed a milky lake. What happened to the ravaged lady is not told here. ${ }^{27}$ The other gods deliberated that this precious first seed should not get lost. They threw it into the fire

27 In fact her name is Ușas, Dawn. She re-emerges in other stories and came to fame as the first rosy shimmer over the horizon, to be greeted with reverence every morning. 
(literally: "surrounded it with Agni"), in a reverent act of sacrifice. And from this first sacrificial gift, this first oblation, sperm, all beings came forth. ${ }^{28}$

The first female had gracefully entered the stage, and yet it was a failed attempt. She had been evoked by Prajāpati's loneliness, but her role had been merely to raise his desire and elicit his sperm. Creation, in this narrative, once more took place through a sacrificial gift (sperm, a milk-like lake) thrown into the sacrificial fire as the first oblation. This first woman had proved no success so far, or putting it mildly, had merely been instrumental, whereas sacrifice, once again, had been successful. Exit woman, for now. Remaining, on that stage, as main characters: an all-male gathering around the sacrificial fire. And truly, this is what Vedic sacrifice looks like until today: an all-male gathering around the sacrificial fire, a collection of technicians of the sacred, busy repeating and re-enacting those first cosmogonic events.

4

A Blueprint

After having introduced a selection of text passages - selected by my own associative thinking rather than by text-historical and text-inherent boundaries I have patched together a minimum of a founding narrative. It may serve as a possible explanation of the institution of sacrifice as a generative act as well as offer a clue to the institution of sacrifice as a repetitive act.

Not only was sacrifice considered the very source of things, sacrifice must be repeated over and over again as an act of maintenance and rejuvenation. This needs some explanation. One of the reasons why the original cosmogonic sacrifice had to be regularly repeated in the human realm is found in the Vedic struggle with the passage of time, and subsequently with dissipation and death. Why was it that sacrifice became the overriding concern of Vedic ritualists? Even if Prajāpati's self-sacrifice may have gloriously been considered the source of all creation, in the mundane world this established order of things was found to be in continuous need of sustenance, as a parallel to Agni who was found to be continuously hungry. ${ }^{29}$

28 Main sources: Bṛhadāraṇyaka Upaniṣad 1.4.1-6; Aitareya Brāhmaṇa 3.33-34; Śatapatha Brāhmaṇa 1.7.4.1-8. On the symbolism of sperm, sperm as a sacrificial gift, sexual unification as sacrifice, and the eating contests during weddings when young men have to eat loads of clarified butter as some kind of fertility ritual, see various works by Wendy Doniger.

29 For parallels in later narratives and sacrificial practices, especially in South India, see David Shulman, The Hungry God: Hindu Tales of Filicide and Devotion (University of Chicago Press: Chicago/London, 1993). 
Just as the phenomenal world was seen to depend on food, the greater order of things was considered to need some form of sustenance. From today's vantage point, it could be stated that the purpose behind the Vedic sacrificial system as a whole was to maintain the established order, $r t a$. The early texts, however, are not only wayward, contradictory and obscure, they are also full of riddles, enigmas and contests that could not be resolved. One of these is the contest in which Prajāpati, the Creator, defeated his rival, Death (Mrtyu). In some extremely dense passages, it is narrated how the deadlock of the longlasting struggle between Creator and Death was broken only by the revelatory vision of the law of equivalence (sampad, samkhyanna). In other words, the moment when that first being, who had engineered creation by cleverly using both his mind and his body, had to stave off this most formidable adversary the threat of time, death and decay, and eventually nothingness - he found that there was a secret key to this universe: the circularity of time. Not acceptance of a mono-linear reality ending in death was the answer to this riddle, but, instead, a deeper insight into time as an endless cycle. Consequently, the key to ongoing existence would be repetition, repetition of the initial sacrifice, rhythmic periodic replenishment. And the basic rule would be the application of the hermetic law of equivalences: "as above, so below", or rather "as once, so now". 30

When this principle of correspondence had provided the master key, the ancient ritualists could break up the contest with Time-Death as an adversary and establish a system to fend off death by closely following time's rhythm with its daily, bi-monthly, seasonal and yearly recurrence. It is exactly on those 'joints' of time that sacrifice is the remedy against the dissipation of energy. Vedic sacrifice is regulated and made effective by equating all ritual acts, all parts, all utensils, all persons, all words, all substances to their original cosmic counterparts, the shattered bits and pieces of the First Being. Those mystically gifted persons who grasped this intricately layered law of correspondences intuited that the same meaningful substance as in the beginning (ägre), in that first cosmogonic act of sacrifice, should be offered into the sacrificial fire at precisely those precarious 'joints' of time. In doing so, repeatedly, painstakingly, they could prevent the inherent threat of depletion that was most real at moments of transition.

This associative logic provided the prescribed rhythm of brahminic sacrifices through days, phases of the moon, seasons and years. It also resulted in the subjection of sacrifice to the exacting rules of ritual. And gradually the institution of sacrifice, yajña, proliferated and came to dominate social life.

30 For a particularly poetic rendering of this passage, see William K. Mahony, The Artful Universe: An Introduction to the Vedic Religious Imagination (sUNY Press: Albany, 1997). 
Ideally, it accompanied not only the calendrical 'joints' of time, but also the transitions from one phase on the axis of individual life to another. This is how, in the domestic domain, crucial life cycle events such as birth, initiation, marriage and death also became occasions for which sacrifices were ordained. Other great transitions, such as the start of a king's rule, were to be similarly marked with sacrifice, although the relationship of king and brahmin was necessarily a contradictory one, based on the opposition between the temporal and the transcendent. ${ }^{31}$

In taking the body of Prajāpati - who had first been central in the cosmogonic process, and then in his conquest of death by the visionary insight into the secret law of correspondence and equivalence - as the grid and basic outline of the year (of which the joints indicated the axial moments in which an act of sacrifice was needed), Vedic ritualists had established a system of extraordinary logic. ${ }^{32}$ This system required the performer not merely to perform well, but also to know and understand. This esoteric 'understanding' later began to have a value of its own, as became manifest in the Upanișadic interiorization of sacrifice and in the Mīmāmusā theory of ritual. The Vedic passages referred to above, thus served, in various ways, as a charter of as well as a blueprint for sacrifice. And they still do so today.

In order to understand cremation as an individual's final (antya) sacrifice (iști), we should keep in mind two crucial insights from the selection of myths and narratives given above: the circularity of time and the centrality of fire.

Agni, Prajāpati's first-born, is likened to a womb (yoni). It is fire into which the sacrificial gift (dravya) is offered. It is fire around which the gods gather to partake in the sacrificial meal. It is fire that transports the sacrificial substances to the gods in the form of smoke (thus starting the naturalistic cycle of smoke-heaven-clouds-rain-new life forms). And it is from fire that all creation once sprung. But Agni may also bring death and destruction, as we saw in the second narrative. Ravenous Fire, once born, turned towards its creator and wished to devour him. Agni was kept at bay by being fed with milk, just as he is now being fed with milk, or another substance derived from milk such

\footnotetext{
31 Jan C. Heesterman. The Inner Conflict of Tradition: Essays in Indian Ritual, Kingship, and Society (University of Chicago Press: Chicago, 1985).

32 Jan Gonda, Prajāpati and the Year (Noord-hollandse Uitgeversmaatschappij: Amsterdam/ Oxford/New York, 1984).
} 
as clarified butter, being poured into the sacrificial fire by the priests. Today this practice of offering libations of milk or butter continues in the frequent homas and havans (simple fire sacrifices) and likewise in the ubiquitous Hindu $p \bar{u} j \bar{a}$, a devotional service in which fire has taken the form of a burning light, such as an oil lamp or clay saucer with a wick drenched in oil.

At the end of the second narrative we found a new dimension: the threat of death. This topic entered the chain of narratives foremost in the sense of the potential threat posed by fire, as fire is eternally hungry and ready to devour anything. On a further note, fire is an efficient way to dispose of discarded matter. This is the point where I zoom in on a particular practice of disposal through fire, the general practice of burning the dead on a pyre. Not only is the habit of consigning a deceased's body to the flames of the funeral pyre one of the most conspicuous uses of fire in the Vedic-Hindu continuum, it is tellingly termed antyesți, the final and ultimate sacrifice. ${ }^{33}$

It is no coincidence that the most common word for a person's final rite of passage indicates a sacrifice. This final rite was traditionally staged as an actual sacrifice, especially in the case when an a ahitāgni (a priest who committed himself to tend his three sacred fires daily) had died. He was consumed by flames generated by embers from his own sacrificial fire, along with all his ritual paraphernalia. His fires thus literally died with him. And his eldest son could only succeed him by setting up his own fires. But not only in the case of an āhitāgni were cremation rites called the final sacrifice; antyești became the general term for that last rite, and it still is, worldwide.

One of the texts says: "And whenever one dies and is placed in the fire, one is reborn from the fire just as he is born from his mother and father (...)."34 One underlying idea was found earlier in our second narrative: burning the body in the cremation fire makes rebirth possible. Fire is creative, and so is the cremation fire. In order to proceed to the next stage, the deceased has to leave his body behind. Fire facilitates the body's disintegration and return to the elements. Already Chāndogya Upanișad 3.17.5 considers death a sacrifice, even the culmination of all sacrifice: it is the final self-sacrifice feeding the funeral fire. Often at this point in a cremation ritual, the locus classicus

33 The antyești is most probably the only rite which involves both a yajña (sacrifice) and a samskära (rite of passage). It should be noted, however, that in death rites it is not the vedi or vihära where the offering is being made, but the pyre. See also Hertha Krick, Das Ritual der Feuergründung (Agnyādheya) (Wien: Verlag der Österreichischen Akademie der Wissenschaften, 1982), p. 5 .

34 Śatapatha Brāhmaṇa 2.2.4.8. 
on the body's return to the elements is quoted literally. ${ }^{35}$ In this way, not only is the cosmogonic sacrificial dispersal of Purușa-Prajāpati's body repeated in the final self-sacrifice of a person on the pyre, the elements of the human body are said to return to their respective elements, thus becoming sacrificially reintegrated into the cosmos. ${ }^{36}$ Fire is both destructive and creative. Fire destroys and turns into ashes what was once a living being, but in doing so it reintegrates the singular body into the cosmos by returning the various body parts to their corresponding cosmic elements. Fire, therefore, is a womb: it gestates. Subsequent rituals should turn the deceased into an established ancestor, and guide him onwards to a new cycle anticipating rebirth, that is, re-creation in some new form.

Death rites should be executed correctly. ${ }^{37}$ They last at least twelve days and theoretically even an entire year. The cremation ritual itself involves all or most of the familiar elements of a sacrifice: fires, purification rites, circumambulation, offerings of gold, clarified butter and other purificatory and alimentary substances, fasting, mantras, gifts, and the services of various officiants. There is no apportionment of the sacrificial substance here, although there are some indications that in the past a cow (or merely its hide) was burned together with the deceased. ${ }^{38}$ Today, in cow-venerating India, a living cow (or its substitute, a piece of gold) may still be given to the officiating brahmin priest.

35 Atharvaveda 17.2. It needs further textual as well as empirical investigation to ascertain that in actual practice the formula for a person's cremation is (supposed to be) the same as that uttered for the sacrificial animal. If so, this would be one more substantiation of cremation as a sacrifice with the body of the deceased as the sacrificial gift. The correspondence between a human body and the elements to which it returns at death evoke the first cosmogonic sacrifice, that of Prajāpati's body from the scattered fragments of which all elements and entities had evolved. The ensuing system of correspondences is based on this rudimentary associative logic: the organ of speech $(v \bar{a} k)$ is supposed to return to fire, the organ of sight/the eye (cakșus) to the sun, the vital force (prāna $)$ to the air, and mind (manas) to the moon.

36 Bṛhadāraṇyaka Upanișad 3.2.13.

37 The most foundational text on ritual practices of dying, death and disposal is the Garu da Purāna. Many priests today use their own manuals. See Jonathan Parry, Death in Banares (Cambridge University Press: Cambridge, 1994); For death rituals in Nepal, especially in Bhaktapur, see Niels Gutschow, Axel Michaels a.o., Handling Death: The Dynamics of Death and Ancestor Rituals among the Newars of Bhaktapur, Nepal (Harrassowitz: Wiesbaden, 2005).

38 The practice of co-cremation, known as sati (or, in colonial spelling, suttee), in which a wife either chose or was forced to accompany her deceased husband in death, followed a completely different line of reasoning too complicated to introduce within the central theme of sacrifice or self-sacrifice. 
Behind the alchemistic notion of a new life rising from the ashes, there is a culture-specific notion prompting elaborate post-funerary rituals. They are considered essential to help the spirit of the deceased to turn from the inauspicious status of a wandering disembodied ghost (preta) into that of an ancestor (pitr). The funeral fire consumes the body - it not only resembles but is a sacrifice - and transports its essence to the gods or the world of the ancestors. It is imagined that it is in the interest of the entire family - its various generations now alive as well as those ancestors waiting to be reborn - that such rites be performed properly. ${ }^{39}$ In these post-pyre rites we see the 'creative' dimension of sacrifice in greater detail. Ashes are normally gathered and kept in a clay pot as long as the ritual impurity lasts. Afterwards the ashes may be scattered over flowing waters or buried beneath a sacred tree. As such even the ashes become part of the re-creative process, literally so.

But there is more. If we take the institution of sacrifice to be the ritual re-enactment of the cosmogonic event in which Purușa-Prajāpati had offered himself as the prototypical victim, then, in the light of the adagium "as above so below/as once, so now" a human person would be obliged to do the same and offer himself as purușāhuti ('man himself as the sacrificial gift') in his own sacrificial fire. If sacrifice is to be an echo or a mirror of that primordial sacrifice, then, to the discerning sacrificer, all other substances given in a lifetime of offerings must be no more than substitutes, postponing the ultimate and 'full' sacrifice (pürnāhuti), the act of offering one's self at the moment of death. In an ancient line of thinking, the body was considered a loan from the gods, especially from Yama, the god of the dead. This debt was to be paid back at the moment of death. ${ }^{40}$ This may have caused the term antyești, ultimate sacrifice, to linger in much wider circles than those privileged to perform sacrifices. Death is democratic: it happens to all. In fact, antyești may well be considered the most wide-spread and democratic instance of the continued salience of Vedic sacrifice.

39 For instance, David M. Knipe, 'Sapiṇịikarana: The Hindu Rite of Entry into Heaven', in Religious Encounters with Death: Insights from the History and Anthropology of Religions, ed. by E. Reynolds and E. H. Waugh (State University Press: London/University Park Pennsylvania, 1997), pp. 112-124.

40 Mark Elmore, 'Contemporary Hindu Approaches to Death: Living With the Dead', in Kathleen Garces-Foley, Death and Religion in a Changing World (Amonk/London: M. E. Sharpe 2006), pp. 23-44. 
The selected narratives provide a speculative clue to the central position of sacrifice in the Vedic-Hindu cultural continuum. Although the actual practice of Vedic sacrifice has declined, it is still alive, and may even undergo a modest form of comeback and rejuvenation. But from very early onwards it did not go uncontested, such as in Buddhist, Jain, and other heterodox milieus, in which especially killing of the animal victim was opposed. In addition to this, as early as the Brāhmanas and Upanișads there were tendencies to prefer a more internalized performance. The tendency to transcend the complicated, contested, and costly material aspects of sacrifice continued and fully emerged in the spread of Hindu theism, bhakti, and vegetarianism. ${ }^{41}$ Moreover, the institution of full-blown ostentatious Vedic practices such as extended Soma-yajña, Atirātra-Agnicayana, Rājasūya, and especially the year-long royal horse sacrifice, the Aśvamedha, may have been regarded by emancipating other classes and castes in Indian society as a clear case of brahmin self-aggrandisement.

In the second half of the twentieth century there was a scholarly tendency to maintain that all such grand sacrifices were dying out, as was also expressed by Frits Staal, in 1975, when he was instrumental in organizing and recording an extensive Agnicayana in Panjal, Kerala. ${ }^{42}$ It was claimed that this venture was unique, being performed by those few Nambudiri brahmin families who had kept an unbroken 3,000-year-old tradition. Its full recording (funded by various American academic associations), including preparation and rehearsals, was regarded justified as a way to keep the minutiae of this particular

41 Such as expressed by Frederick M. Smith, 'A Brief History of Indian Religious Ritual and Resource Consumption: Was there an Environmental Ethic?' (Asian Ethnology 70 (2011), pp. 163-179). One of my own motives for researching cremation rituals in India, Nepal and Bhutan, in that summer of 2011, was a critique of the so-called Religious Environmentalist Paradigm (REP): if indeed South Asian religions and cultures had been (and still is) so environmentally friendly as is often maintained, how could the staggering quantities of dry wood needed for the open pyre be defended in the light of disastrous deforestation today? Albertina Nugteren, 'Wood, Water, and Waste: Mortuary Practices in India and Nepal' (in Roots of Wisdom, Branches of Devotion: Plant Life in South Asian Religions and Culture, ed. by Fabrizio M. Ferrari and Thomas Dähnhardt, in press).

42 The film recording the Agnicayana performance has been released as R. Gardner and J. F. Staal, Altar of Fire (University of California Extension Media Center and Harvard University Film Study Center: Berkeley/Harvard, 1976). The two-volume book was published as Frits Staal et al., Agni: The Vedic Ritual of the Fire Altar (Berkeley: Asian Humanities Press, 1983). See also the Dutch Nos documentary Het vuuraltaar (broadcast on September 8, 1987). 
ritual for posterity before it would become extinct forever. Its documents (an encyclopedic book in two volumes, a film, and audio recordings) presented the Atirātra-Agnicayana of 1975 as perhaps having been "performed for the very last time". But this has been proven wrong. Not only has there been a repetition by the same community of Nambudiri priests in 1990, 2006, and 2011, other grand sacrifices were held in other places. We now assume that comparable grand - scale Vedic sacrifices have been going on in isolated pockets in India at irregular intervals over three millennia, most of them unknown to Western academics and to most Indian priestly scholars as well, for the simple reason that they remained mostly unrecorded.

In a fascinating article, 'Veda on Parade: Revivalist Ritual as Civic Spectacle', Timothy Lubin relates how he - more or less accidentally - became one of the celebrities in a many-days long Vedic sacrifice in rural Maharashtra, in 1992. One of the article's insights is supported by attention the author pays to what goes on in the margins. He thus confirms earlier observations in fieldwork done by colleagues that contemporary Vedic sacrifice may still be done by the book', but simultaneously, especially in off-center ritual activities, becomes a form of Hindu pūjā. By shifting his gaze occasionally to non-ritualized or peripheral ritual activities taking place at the margins, such as devotion shown in front of additional shrines for deities and gurus, museum-like displays including plaques mentioning the technical name of each item in the sacrifice, printed publicity, and open proselytizing, Lubin shows how both continuity and change become obvious. ${ }^{43}$

Likewise, Frederick M. Smith, in a contribution titled 'Indra Goes West: Report on a Vedic Soma Sacrifice in London', comments on an elaborate Vedic sacrifice performed in Roundwood Park, London, in 1996. ${ }^{44}$ Silke Bechler refers to a 1,008-hour sacrifice in Bad Meinberg, Germany, held in 2008, and even more could be mentioned. ${ }^{45}$ These cases not only illustrate that ritual knowledge is stored in texts as well as in bodies, oral transmissions, and collective

43 Timothy Lubin, 'Veda on Parade: Revivalist Ritual as Civic Spectacle', Journal of the American Academy of Religion 69 (2) (2001), pp. 377-408.

44 Frederick M. Smith, 'Indra Goes West: Report on a Vedic Soma Sacrifice in London', History of Religions 36 (3) (2000), pp. 247-267.

45 Silke Bechler, "Globalized Religion: The Vedic Sacrifice (Yajña) in Transcultural Public Spheres”, Asia Journal of Global Studies 4 (1) (2010/2011), pp. 21-34, as well as in Derrick Nault et al. (eds), Experiencing Globalizations: Religion in Contemporary Contexts (Anthem Press: London, 2013), pp. 59-77. See also of the same author, 'The Performance of Contemporary Vedic Sacrifices in Private and Public Spheres of India', in Axel Michaels and Christoph Wulf (eds), Emotions in Rituals and Performances (Routledge: New Delhi, 2012), pp. 250-256. 
memories, but also that the need for certain rituals may rise and wane, and reappear with slightly different metanarratives. What was once expressed as a need to reinforce elementary powers for the rejuvenation of the cosmos, or to build up an immortal body for the sacrificer, may now also be expressed in terms of scholarly, didactic, artistic, and touristic purposes.

But this focus on the more spectacular and grand Vedic sacrifices, which almost vanished from the ritual arena with the arrival of temple worship and the Āgamic pūjā, may obscure that a considerable number of Hindus still practice the five great daily sacrifices (pañca-mahāyajñas) in a simplified form, discretely, devotedly, without any spectacle, at home. ${ }^{46}$

Perspectives

Ethnographic accounts of actual sacrifices in contemporary South Asia or even diasporic contexts throw new light on the diversity, ritual dynamics, and shifts in underlying motives for the continued performance of sacrifices. Some aspects of South Asian sacrificial traditions have even selectively been appropriated by a new type of global entrepreneurs in the spiritual supermarket or integrated into art projects by artists such as Wolfgang Laib. ${ }^{47}$

Vedas and Vedic ritual have, theoretically, a high status, although the actual practice of full-fledged Vedic ritual has long been marginal. Ongoing Vedic practice in several rural areas had remained largely undetected and below the radar screen of (Western) scholars. Today we even notice a modest comeback: no one could have foreseen the recent emergence of energetic sponsorship among brahmin traditionalists, vigorous patriots, and even diasporic communities such as in New York after ' $9 / 11$ '. Vedic sacrifices are now typically promoted as at once eternal and modern-scientific. ${ }^{48}$ Their supposed rain-producing effects

46 This fivefold daily sacrifice consists of the following: devayajña (an offering to the gods), pitryajña (offering to the ancestors), bhütayajña (offering to the spirits), nryajña (offering to humans, i.e., generosity), and brahmayajña (offering to Brahma, i.e., study). The most ancient source for this is probably Śatapata Brāhmaṇa 11.5.6.1-3.

47 Wolfgang Laib's exhibition in the Fondazione Merz, Turin, Italy, in 2009, started with a Vedic fire ritual in South India, and closed with a second fire ritual in Turin, "celebrated by 45 Brahmin priests from one of the most important temples in South India (...) It is about creation, sustenance and destruction and renewal (...) This is a unique cultural event that can rarely be witnessed in a Western country (...)." Source: http://fondazionemerz.org/ en/eventi/rito-del-fuoco/, accessed October 14, 2011.

48 Typically phrased by one of the Brahmin scientist-priests, head of the research team for the twelve-day Atirātra sacrifice in the village of Panjal, Kerala, April 2011: "The essence 
are applied to the domains of public health and environmental well-being. It goes without saying that many oppose this trend, for various reasons. ${ }^{49}$

Apart from the slightly frivolous recent developments, there is another reason why the Vedic sacrificial system continues to fascinate. In the words of life-long Vedic scholar Jan Gonda: "No other nation of antiquity has left us so detailed, considered, and systematic descriptions of their ritual and ceremonial as the Vedic specialists. ${ }^{50}$ Indeed, Vedic sacrifice continues to offer much food for thought. And the open cremation fire, with which this article started, is one of the most obvious and ubiquitous illustrations of this.

of the ritual is pure science. It is a way of celebrating the big bang or the creation of the universe which began with a ball of fire." ('Age-old Kerala Fire Ritual a Natural Purifier?' Times of India, May 12, 2011).

49 See also Times of India January 18, 2011 ('Stoking a Vedic Fire'); June 13, 2011 ('Rekindling a Vedic Fire Ritual'); and July 16, 2011 ('Trial by Fire'), and www.parihara.com on April 15, 2011 ('Rain Lashes Kerala Village as Fire Ritual Ends') posted by Madhusree Chatterjee. Accessed October 14, 2011.

5o Jan Gonda, The Ritual Sūtras (Wiesbaden: Harrassowitz, 1977), p. 470. 